\title{
Discourse of doubt: The testing of apocalyptic figures in Jewish and Christian traditions of Late Antiquity
}

\author{
Helen Spurling ${ }^{*}$ \\ Department of History and the Parkes Institute \\ University of Southampton
}

\begin{abstract}
This paper will examine Jewish and Christian apocalyptic literature of the seventheighth centuries to discuss a shared 'discourse of doubt' that cuts across different religious traditions. This discourse is manifested in the doubts of different sections of society regarding the end of time and their place in the future world, and the associated requirement that major apocalyptic figures undergo tests to prove their identity, most commonly through performing the miracle of resurrection. This discourse indicates the need to endorse the religious claims of a given group, which in turn reflects the wider political turmoil of the seventh century and a search for identity and clarification of status in uncertain times. The analysis presented here not only contributes to discussion on the relationship between Jewish and Christian apocalyptic writings of this period, but highlights what potential contacts and conflict as evidenced in this literature can reveal about the state of Jewish-Christian relations at a formative period for the Abrahamic religions.
\end{abstract}

Keywords: apocalyptic literature, seventh century, Jewish-Christian relations, Sefer Zerubbabel, Otot ha-Mashiah, Pirqe Mashiah, messianism, miracles, resurrection

\section{Introduction}

The seventh and eighth centuries, with the Byzantine and Sassanid conquests along with the rise of Islam, is a crucial period in the history of the relations between Jews, Christians and Muslims in the Eastern Mediterranean. It was a time of political change and turmoil but also an age when religious identities were challenged and religious claims were emphasised. This article will examine claims to religious authority through analysis of apocalyptic and eschatological traditions as evidenced in Jewish and Christian writings of this period. Jewish and Christian apocalyptic literature received a new impetus in the seventh-eighth centuries when political events, including the Sassanid and then the Arab conquests, were regarded as a sign of the messianic era. This so called 'revival' is highlighted, perhaps most famously, by Sefer Zerubbabel on the Jewish side and Pseudo-Methodius on the Christian side, but these texts are part of a broader outpouring of apocalyptic writings in the seventh-eighth centuries that can shed light on contemporary attitudes to events, perspectives on 'other' socioreligious groups, and perceptions of religious authority as manifested in theological claims. ${ }^{1}$

It is with interest in the relationship between Jewish and Christian apocalypticism that this article focuses on analysis of a particular motif shared across these different traditions: what can be described as a 'discourse of doubt' reflected in the need for key apocalyptic figures to demonstrate the validity of their identity and claims. This theme is a prominent feature of both Jewish and Christian apocalypses from the seventh-eighth centuries, with

\footnotetext{
*H.Spurling@ southampton.ac.uk
} 
numerous parallels in approach albeit representing very different theological perspectives. These traditions of doubt and testing of eschatological leaders highlight the close connections between Jewish and Christian apocalypticism, but are also part of a wider discourse of competing claims reflected in Jewish and Christian literature from this period. The events of the seventh-eighth centuries prompted the wide circulation of apocalyptic ideology and traditions, which was connected with an underlying motivation for scholars of different traditions to validate the religious claims of their particular group or community in light of the changing political circumstances in the Eastern Mediterranean.

Here the focus will be on examination of the Jewish sources Sefer Zerubbabel, Otot ha-Mashiah and Pirqe Mashiah. ${ }^{2}$ Produced in the aftermath of the Sassanid Persian conquests in the early seventh century, Sefer Zerubbabel is widely acknowledged as the locus classicus Jewish apocalyptic work of this period and sets the foundation for subsequent apocalyptic writings. Otot ha-Mashiah also from this period offers an interesting development of the 'discourse of doubt' in relation to the satanic figure of Armilos, and Pirqe Mashiah represents a fully developed exploration of doubt and testing of the Messiah in the context of the Arab conquests. These compositions will be assessed with reference to contemporary Christian apocalyptic sources. Pseudo-Methodius, widely dated to the seventh century, will be examined as the foundational Christian apocalyptic text, and the Syriac Apocalypse of Daniel will also be explored due to its development apparently without knowledge of Pseudo-Methodius. These sources represent a selection of diverse but influential apocalyptic traditions from the seventh-eighth centuries, which will be analysed in terms of how they reflect the heightened need to explain and emphasise theological claims of authority in the Eastern Mediterranean in this period, and in ways that shed light on a shared 'discourse of doubt'.

\section{The Despicable Messiah: Sefer Zerubbabel}

Sefer Zerubbabel is perhaps the most widely known and discussed Jewish apocalyptic text of the seventh century. ${ }^{3}$ The apocalypse is dated to this period largely on the basis of a concern for the role of the Persians in the final redemption of Israel. This is highlighted by the title of the text as the 'Book of Zerubbabel', the governor of Judah who led the Jewish people following their restoration by the Persians after exile in Babylonia. ${ }^{4}$ Jellinek's edition of the text possibly alludes to Kavad II, the Sassanid Shah who brokered a peace deal with Heraclius in c.628-630 to end the current round of Byzantine-Persian warfare, restore territory to Heraclius and secure the return of the True Cross taken from Jerusalem. ${ }^{5}$ The apocalypse reflects the political instability of the early seventh century, and Jewish hopes and expectations for restoration raised by the Persian conquests and then dashed by subsequent withdrawal. Presented as a vision delivered to Zerubabbel ben Shealtiel, while in exile in Babylonia, the apocalypse addresses the question of when the Messiah and hoped for vindication at the end of time will come. It builds on and fully develops eschatological themes often familiar from earlier rabbinic traditions, including material on the Messiahs of Joseph and David, the status of Jerusalem and the Temple, the Day of the Lord and Gog and Magog, the resurrection of the dead, and the rule and defeat of Armilos. ${ }^{6}$ It is without doubt of major significance for understanding a Jewish response to the Persian conquests and attitudes to Christians and Christian traditions in this period. ${ }^{7}$ For the purposes of this article, the focus is on the motif of doubt, which is found in Sefer Zerubbabel in connection with the identification of the Messiah ben David.

In Sefer Zerubbabel, the identity of the Messiah ben David appears suspect because of his lowly and despicable appearance. Zerubbabel is taken to Rome where he sees a man who 
is 'despicable and wounded' (נבזה ופצוע). ${ }^{8}$ Zerubbabel questions this individual as to his identity and receives the response that 'I am the Messiah of the Lord and I am bound here until the time of the End'. Zerubbabel is taken aback and remains silent, but, upon further questioning and encouragement by Menahem ben 'Ami'el, Zerubbabel acknowledges that he is indeed speaking to the Messiah ben David. ${ }^{9}$ This affirmation results in the transformation of the Messiah from a despicable character into a handsome young man. ${ }^{10}$ It is clear that Zerubbabel's recognition that he is in the presence of the Messiah allows him to see the true nature of the person to whom he is speaking. Thus, the principle of the importance of recognition is found with regard to apocalyptic leadership. Zerubbabel as governor of the Jewish people and of the Davidic line is suitably righteous to be able to understand the significance of who is in front of him.

In contrast, however, Zerubbabel is informed that, when it comes to the end times and the revelation of the Messiah ben David, resistance and doubt will be the first response of the Jewish leadership:

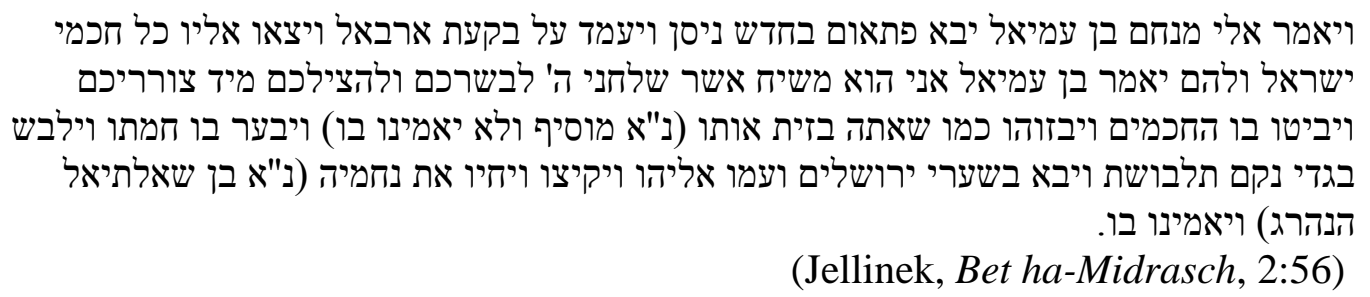

He said to me: 'Menahem ben 'Ami'el will come suddenly in the month of Nisan. He will stand by the Valley of 'Arb'el, and all the sages of Israel will go out to him. Ben 'Ami'el will say to them: "I am the Messiah sent by the Lord to bring good tidings to you and to deliver you from the hand of your adversaries!" The sages will look at him and will despise him, just as you despised him (gloss adds: and they will not believe in him). Then his anger will burn within him, 'And he will dress in garments of vengeance as clothing' (Isaiah 59:17), and he will enter the gates of Jerusalem, and with him will be Elijah. They will awaken and resurrect Nehemiah (gloss: ben Shealtiel who was killed) ${ }^{11}$ and they will believe in him.

The text describes how Menahem ben 'Ami'el will appear in the month of Nisan near the Valley of 'Arb'el. All the sages of Israel - those amongst the rabbinic leadership who have survived the tribulations of the Day of the Lord and Gog and Magog - will go to meet him. Menahem ben 'Ami'el will announce his identity as the Messiah sent by God to deliver Israel from the nations of the earth led by Armilos. However, the sages will 'look at him and will despise him' because of his lowly appearance, which is not in keeping with traditional concepts of a grand messianic deliverer often associated with the final battles of the end of time. $^{12}$

Further actions are then undertaken in order to convince the sages that Menahem ben 'Ami'el is indeed the Messiah. First, the Messiah must undergo a transformation. He puts on garments of vengeance, in accordance with the prophecy in Isaiah 59:17, thus showing that he is indeed the expected Messiah in fulfilment of biblical prophecy. ${ }^{13}$ Secondly, Menahem is accompanied by Elijah. The return of Elijah at the end of time, based on Malachi 3:23, to assist the Messiah in the events of the messianic age has a long exegetical history. ${ }^{14}$ Thus, the fact that the Messiah is accompanied by Elijah is a further affirmation of his authority and identity. Finally, it is not until the Messiah ben David resurrects Nehemiah, the Messiah ben Joseph who was slain, that the sages in Israel will believe in him. In this way, a simple 
proclamation of the Messiah's identity is insufficient for the Jewish leadership to accept his claims and believe in him. It is only once Menahem ben 'Ami'el has conducted the miracle of resurrection that the credibility of his leadership is affirmed. Interestingly, in contrast to Zerubbabel who recognised the Messiah even whilst disguised as a broken down man, it is only after the Messiah's glorious transformation that the sages of Israel are able to accept his claims. Even then, the transformation alone is not enough and it is the miracle of resurrection that finally convinces them. This could represent real concerns amongst the Jewish leadership, and thus possibly a reflection of the views of a wider Jewish population of the seventh century, as to how the Messiah may be identified, given the widespread understanding of the seventh century as the time of the end of the world. Such concerns should be viewed against the context of the competing religious claims of the seventh century as manifested in Christian and subsequently Islamic writings, and the need for clarification and 'proof' of the authority held by religious claimants that may appear on the scene. ${ }^{15}$

\section{The Trickery of Armilos: Otot ha-Mashiah}

In a different way, the importance of a test of credibility is also found in Otot ha-Mashiah, which outlines the ten signs of the messianic age. Signs of the end of time are a wellestablished feature of Jewish and Christian apocalyptic writing from the Second Temple period onwards, but in Otot ha-Mashiah a more fully developed form of older traditions, along with innovative material, can be found. The version of the text in Jellinek's Bet haMidrasch is best described as a compilation of apocalyptic traditions, but Boustan and Sivertsev have argued recently (with due qualifications) that it belongs to the seventh century. ${ }^{16}$ The apocalypse describes a time of apostasy and failed leadership when the 'evil empire', namely Edom, or Rome, has sovereignty.

Ten signs that this is the end of the age are outlined, including the appearance of evil creatures, extreme heat and disease, a world filled with a dew of blood, followed by a dew of healing, the darkening of the sun, the rule of Edom leading to the appearance of the Messiah ben Joseph, the activities of Armilos, the revelation of the Messiah ben David and the Day of the Lord, the resurrection of the dead and final judgement and reward. All these signs are described in relation to the righteous and the wicked and connected to questions of religious faithfulness, apostasy and the practices of the gentile nations. This apocalypse is of particular interest for its portrayal of the non-Jewish 'other', but also its development of apocalyptic traditions such as the description of Armilos, presented as the seventh of the ten signs, and which portrayal is of particular relevance to the question of a discourse of doubt.

The seventh sign provides an elaborate description of the rise of Armilos the Satan who is explicitly equated with the Antichrist of the gentile nations (אנטיקרי'שטו' ${ }^{17}$ In Otot ha-Mashiah, Armilos asserts that he is the Messiah, and first the Edomites followed by the other nations of the world believe in him. The language is critical of their blind acceptance with an emphasis on how they 'immediately' accept his claims and leadership. Armilos asks the descendants of Esau: 'Bring before me my revelation (תורתי) which I gave to you!' and the text says that they will bring him their 'frivolity' (תפלותם). Armilos affirms that this is indeed his revelation and his Messiahship is affirmed. This represents an explicit critique of the religious views of the nations of the world and the descendants of Esau in particular. As is well known, Esau is often a pseudonym for the Christian Roman/Byzantine Empire, ${ }^{18}$ and the representation of Armilos in Otot ha-Mashiah can be seen as a means of critiquing specifically Christian teachings. ${ }^{19}$

In contrast to the nations of the world, Nehemiah the Messiah ben Joseph is commanded to bring the Torah and declare that Armilos is God, but he reads out the 
commandment 'you shall have no other Gods before me' (Exodus 20:3). Armilos claims, wrongly of course, that this is not to be found in the Torah and so Nehemiah and his warriors are able to identify him as a false Messiah. For the Jewish redactor, it is knowledge of Torah that allows the generation of the eschatological age to identify that Armilos is not their ultimate saviour, and is trying to deceive them. In this way, the merit of receiving Torah and proper knowledge of it is not only a sign of the elect status of the Jewish people, but is the means of Israel's deliverance at the end of time. This emphasis on the importance of Torah is clearly a standard theme throughout Jewish writings of the rabbinic era, ${ }^{20}$ but takes on special relevance in relation to Jewish election in light of the heightened tension over rival claims in the seventh and eighth centuries. ${ }^{21}$

Interestingly, the testing of apocalyptic figures is also connected to questions of doubt by the Jewish people in Otot ha-Mashiah. Following the death of Nehemiah at the hands of Armilos, the Jewish people lose courage and suffer at the hands of the nations of the world. The discourse of doubt then ensues:

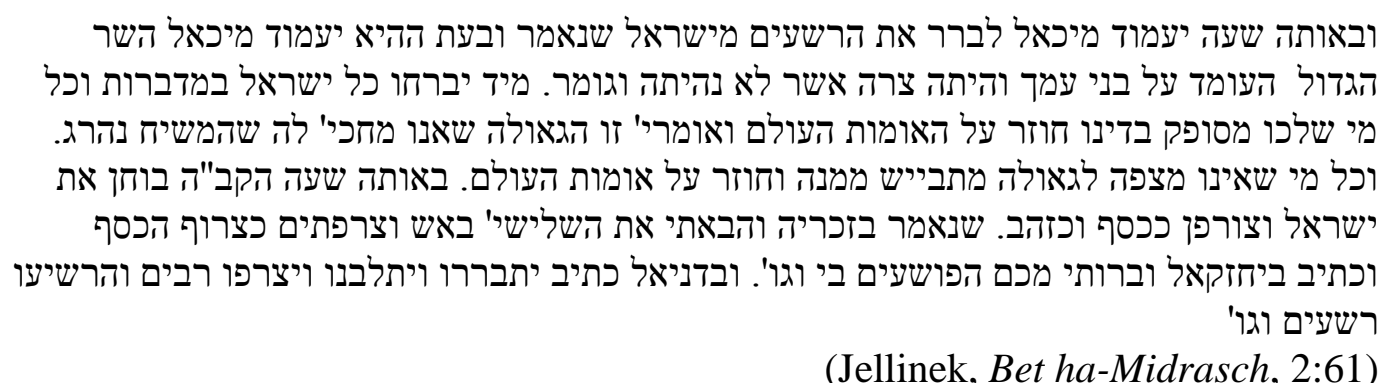

At that moment, Michael will arise to purge the wicked from Israel, as it is said 'At that time Michael, the great prince, the protector of your people, shall arise. There shall be distress, such as has never occurred, etc.' Immediately, all Israel will flee into the deserts, and everyone who casts doubt on his judgement will turn to the peoples of the world and say: "Is this the redemption for which we have been hoping, for the Messiah has been killed!" And everyone who is no longer waiting for redemption will be ashamed on account of it and will turn to the peoples of the world. At that moment, the Holy One, blessed be He, will test Israel and refine them like silver and like gold, as it is said in Zechariah: 'And I will bring the third part into the fire, and I will refine them as one refines silver' (Zechariah 13:9), and it is written in Ezekiel: 'And I will purge from among you the ones who transgress against me, etc.' (Ezekiel 20:38), and in Daniel it is written: 'Many will be purged and be made white and be refined, but the wicked will behave wickedly, etc.' (Daniel 12:10).

This tradition in Otot ha-Mashiah is an interpretation of Daniel 12:1, which states that Michael will arise at a time of turmoil, and a righteous remnant - all those who are written in the book - shall be delivered. This is a time of testing for the Jewish people by God to see who will remain faithful. The text describes the wicked among Israel who explicitly 'cast doubt' (שלכו מסופק) on redemption. They are ashamed that their hopes have come to nothing because the Messiah is dead and as a result turn to the nations of the world. The theme of apostasy is explicitly connected to testing through reference to a series of relevant proof texts: Zechariah 13:9, Ezekiel 20:38 and Daniel 12:10. ${ }^{22}$ Daniel 12:10 is the connecting verse here, which refers to both purging (ברר) as in Ezekiel 20:38, and refining (צרף) as in Zechariah 13:9, and links back to the base verse of Daniel 12:1. All three proof texts highlight that a 
period of refining and testing of the people is to be expected in fulfilment of biblical prophecy, after which the wicked will be identified (i.e. those who commit apostasy) and purged. Only those who pass through this period of testing and remain faithful will see the victory brought by the Messiah ben David.

Thus, Otot ha-Mashiah explicitly addresses the problem of doubt and associated apostasy, demonstrating a clear concern for those who do not believe or turn away from Israel. This encouragement to stay faithful reflects the need to explain how to deal with the turmoil facing the Jewish people in the seventh century; it is a period of testing in light of

competing religious claims before the end of the world and ultimate victory arrives. ${ }^{23}$ The context of religious competition is explicitly acknowledged in this text through reference to the 'frivolity' of the descendants of Esau, and the 'doubts' about their religious position experienced by the Jewish survivors in the desert. However, Otot ha-Mashiah emphasises that, as Nehemiah's actions proved, it is knowledge of and adherence to the Torah that will ensure a place for the righteous in the final vindication.

\section{Testing the Messiah: Pirqe Mashiah}

Pirqe Mashiah contains the most detailed elaboration of the theme of doubt and testing with regard to apocalyptic figures. ${ }^{24}$ The text is a compilation of eschatological traditions on the messianic age and the future world, with special focus on the status and ultimate redemption of the Jewish people centred on Jerusalem. Although a compilation, at least a stage of redaction can be dated to the period of the rise of Islam on the basis of historical allusions to

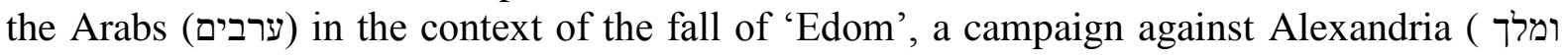
מלך פרס מתגרה (גדול יצא על אלכסנדיאה במחנה (במה ערכה מלך came with the Arab conquests and subsequent rule from the seventh century onwards, and provides an insight into Jewish-Christian-Muslim relations at that time.

In Pirqe Mashiah, the Messiah ben David has a crucial role, and provides an arresting illustration of the theme of doubt and testing due to detailed descriptions concerned with how to identify the Messiah ben David when he is revealed at the end of time. These are not simply the well-known 'signs' or 'portents' of the Messiah and the last days, but elaboration of miraculous tests, which enable the Jewish people to have confidence that a messianic figure is indeed who he claims to be, or, conversely, enable the people to root out false eschatological figures. In Pirqe Mashiah, Elijah and the King Messiah appear to Israel in the desert. Elijah exhorts the people to arise, but they do not believe that the Messiah has indeed arrived. Pirqe Mashiah clearly highlights the doubts of the Jewish people over how to identify the Messiah and we find the statement that: 'they will not believe in him because ואינם מאמינים בו לפי שבא נחמיה (the Messiah ben Joseph] came and was killed' ונהרג). ${ }^{26}$ The people even go as far as to request proof of identity, just as Moses proved the legitimacy of his mission by means of miracles: "And he will say to them: "Perhaps you are

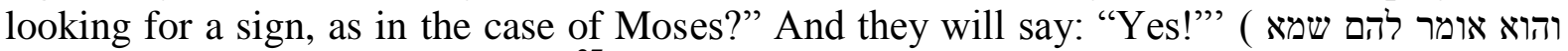
אתם מבקשים אות כמשה והם אומרי' הן ${ }^{27}$

Seven miracles are conducted by the Messiah in order to prove his identity, and the miracles performed for the Jewish people are evocative of the Exodus story, thus linking the first redemption with a Second Exodus or redemption at the end of time. ${ }^{28}$ Those who have survived the events of the Day of the Lord so far are in the desert searching for food, thus recalling the first Exodus experience and drawing a parallel between Moses who needed to perform signs in order to assuage the people's doubts and the Messiah ben David. The miracles performed by the Messiah are diverse, but there is a particular emphasis on the 
importance of resurrection. For example, the first miracle brings Moses and his generation from the desert and the second miracle sees the resurrection of Korah and all his assembly. The resurrection theme is continued for the third miracle which is the revival of Nehemiah the Messiah ben Joseph who was slain. The fourth miracle reveals the hidden jar of manna and anointing oil with which Moses anointed the altar and vessels of the Tabernacle. Finally, the fifth miracle brings the staff of Moses, through which the original signs were performed. The last two miracles move onto signs of the Day of the Lord and events that mark the transition from this age to the next; for the sixth miracle, the Messiah 'will grind all the mountains of Israel like chaff', based on Isaiah 42:15, and, for the seventh miracle, 'will reveal to them the secret', which is most probably the secret of the time of redemption based on Genesis 9:12,17. ${ }^{29}$

Interestingly, these signs do not secure the faith of the Jewish people long term, as, following the Day of the Lord, the Jewish people question the identity of the Messiah ben David yet again, and ask if he is the one predicted in biblical prophecy, which he confirms:

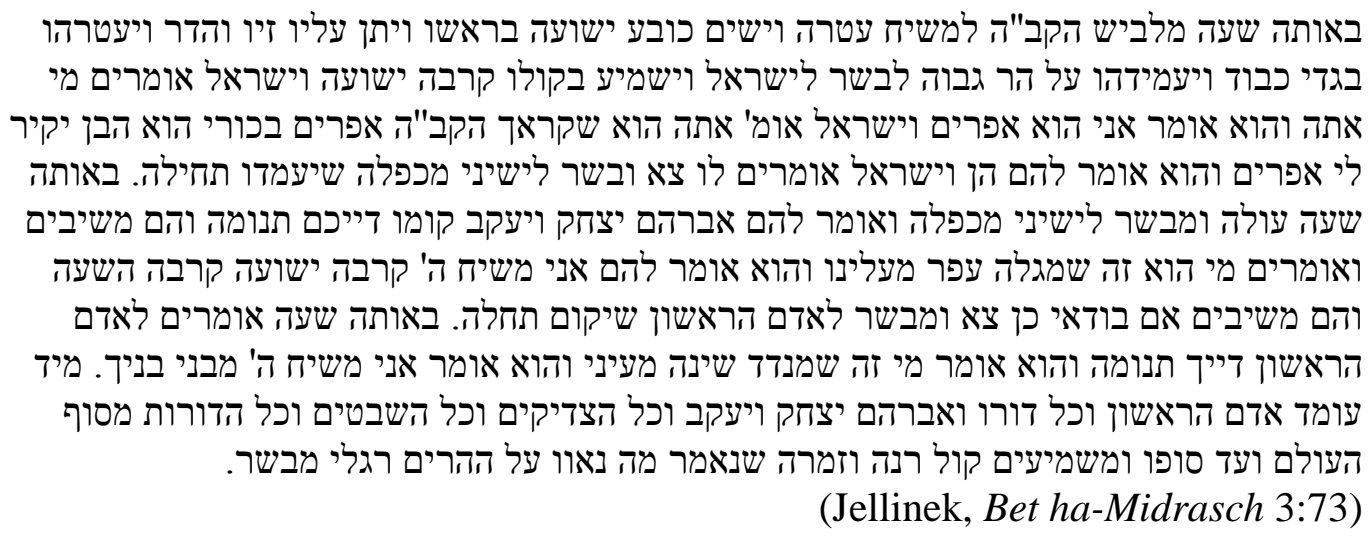

(Jellinek, Bet ha-Midrasch 3:73)

At that moment the Holy One, blessed be He, will put a crown on the Messiah and set 'a helmet of salvation on his head' (Isaiah 59:17), and he will give splendour and glory to him, and he will adorn him with garments of honour, and he will make him stand upon a high mountain to bear good tidings to Israel, and he will proclaim: "Salvation is near". And Israel will say: "Who are you?" And he will say: "I am Ephraim". And Israel will say: "Are you the one whom the Holy One, blessed be He, called 'Ephraim is my firstborn' (Jeremiah 31:9), and 'Ephraim is a son dear to me' (Jeremiah 31:20)?" And he will say to them: "Indeed". And Israel will say to him: "Go out and bear good tidings to the sleepers of Machpelah that they should arise first". At that moment he will go up and bear good tidings to the sleepers of Machpelah, and say to them: "Abraham, Isaac and Jacob! Arise! You have slept enough!" And they will respond and say: "Who is this who uncovers the dust from upon us?" And he will say to them: "I am the Messiah of the Lord. Salvation is near! The hour is near!" And they will reply: "If it is indeed so, go out and announce to the first man that he might arise first". At that moment they will say to the first man: "Enough of your slumber!" And he will say: "Who is this who chases the sleep from my eyes?" And he will say: "I am the Messiah of the Lord from the sons of your sons". Immediately the first man will arise and all his generation, and Abraham, Isaac and Jacob and all the righteous and all the tribes and all the generations from one end of the world to the other end, and they will sing loudly, as it was said, 'How beautiful upon the mountains are the feet of the one bringing good tidings' (Isaiah 52:7). 
This passage begins with an emphasis on the glorious nature of the Messiah, based on Isaiah 59:17. An image is presented that conforms to traditional connections between messianism and royalty; the Messiah is crowned and honoured by God. However, the Messiah ben David, despite the extensive miraculous activity previously conducted, is asked to identify himself. The Messiah responds with the claim 'I am Ephraim' (אני הוא אפרים), to which Israel asks the Messiah if he is the one known as Ephraim in Jeremiah 31:9 and Jeremiah 31:20, which he confirms. In the Hebrew Bible, the name Ephraim in these verses is identified with Israel, an identification also found in the Tg. Jeremiah 31:9 and 20, Pesiqta de-Rav Kahana 24.16, Pesiqta Rabbati 10.5, 21.11 and Midrash on Psalms 77.2. The title Ephraim is also often applied to the Messiah ben Joseph, but this is not a well-attested name for the Messiah ben David. ${ }^{30}$ In Pirqe Mashiah, these verses are applied to the Messiah to show that he is acting in fulfilment of biblical prophecy. In particular, the use of Jeremiah 31:9 and 31:20 in Pirqe Mashiah alludes to the salvation, repentance and return of the exiles, which is the context of these verses in the Hebrew Bible. The return of exiles based on these verses is a well-attested tradition. For example, Tg. Jeremiah 31:9 explicitly interprets these verses in relation to the return of the exiles, Genesis Rabbah 93.12 and Exodus Rabbah 38.4 relate Jeremiah 31:9 to the salvation and redemption of Israel, and Midrash on Psalms 18.11 connects the resurrection with the return of exiles based on Jeremiah 31. As such, in citing these scriptural quotations, it becomes clear that a key function of the Messiah ben David in Pirqe Mashiah is the ingathering of the Diaspora. ${ }^{31}$

To prove that he is indeed the Messiah, Israel requests that he conducts the resurrection of the dead beginning with the 'sleepers of Machpelah'. ${ }^{32}$ The statement that the sleepers will 'arise' (קומו) refers to the resurrection. ${ }^{33}$ Israel claims that the Patriarchs should be resurrected first of all. The Messiah addresses them and tells the Patriarchs that they have slept enough (דייכם תנומה), ${ }^{34}$ but their first response is to ask him to explain who he is and they say 'Who is this who uncovers the dust from upon us?' (מי הוא זה שמגלה עפר מעלינו). Thus, even the Patriarchs ask the Messiah to affirm his identity, and, when stating that Adam should be the first to enjoy resurrection, they still provide a qualification to their request by saying to the Messiah 'if it is indeed so' (אם בודאי כן). The Messiah goes to Adam who also asks him to identify himself, but upon announcing that he is 'the Messiah of the Lord from the sons of your sons', the resurrection of Adam takes place followed by the general resurrection of the dead. Pirqe Mashiah describes how the first man will arise (literally 'stand up') and all his generation. The description of those who are resurrected as 'standing up' alludes to Ezekiel 37:10, where the dead are said to stand on their feet and live. In Pirqe Mashiah, it is Adam and his generation, the Patriarchs, the righteous, the tribes and finally all of the generations to have existed in the world who are resurrected. There is thus a universal or general resurrection in Pirqe Mashiah, which acts as the precursor to the last judgement. ${ }^{36}$ In conducting the resurrection, the Messiah ben David has provided the 'proof' required by the Jewish people that he is truly the Messiah, and the appropriate rejoicing over the message of salvation brought by the Messiah ensues in fulfilment of Isaiah 52:7. ${ }^{37}$

There is clearly a fully developed concern for the proper identification of the Messiah ben David in Pirqe Mashiah. In addition to highlighting that the actions of the Messiah are the fulfilment of biblical prophecy and expectation, his authority and claims are further verified through elaborate miraculous activity. Interestingly, there is a particular emphasis on the importance of the ability to resurrect as a sign of 'true' authority, as seen in the first three signs in the desert (of Moses and his generation, Korah and his assembly and the Messiah ben Joseph) followed by the general resurrection of the dead. This need for testing of the Messiah again reflects concerns over competing religious claims, a conclusion which is further supported by explicit reference to disputes with a 'gentile or a heretic' (גוי או מין) within the compilation. ${ }^{38}$ The statements of the goyim and mimim are not mentioned specifically in 
relation to the Messiah in Pirqe Mashiah, but are cited with regard to how to respond to an opponent's arguments on questions of the status of Israel and Jerusalem in the future. Although the identity of these opponents is uncertain, ${ }^{39}$ the fact that reference to rival views has been included in Pirqe Mashiah indicates that the text has been compiled to assure its Jewish audience of their place in the world - both this one and the next - in light of alternative religious claims.

\section{Testing and Authority in Christian Apocalypticism}

The theme of testing for genuine claims of authority in the end times can also be found in Christian apocalypses from this period. Pseudo-Methodius is the classic Christian apocalyptic text reflecting responses to the rise of Islam, and is dated by consensus to the seventh century. ${ }^{40}$ The apocalypse describes the history of the world in seven millennia with the events of the author's day as taking place in the seventh and final millennium as the end of days. Pseudo-Methodius describes at length the impact of the conquests of the 'sons of Ishmael', which it views as a time of chastisement for the faithful Christian: 'People will undergo chastisement by the Ishmaelites; they will enter into various afflictions to the point of despairing of their lives. Honour will be taken away from priests, the Divine Office and the Living Sacrifice will come to an end in the Church; priests will be like the people at that time'. ${ }^{41}$ The apocalypse presents a vivid concern for life and the future under Arab rule with reference to taxation, improper Christian behaviour and potential apostasy: 'Many people who were members of the Church will deny the true Faith of the Christians, along with the holy Cross and the awesome Mysteries'. ${ }^{42}$ The text famously describes the 'King of the Greeks', the Last Emperor, who will bring about restoration of Christian rule and a time of peace prior to the final events of the last days. The time of the Last Emperor will also witness the arrival of the Son of Perdition, a false Messiah who must be defeated prior to the Second Coming of Jesus. ${ }^{43}$

It is with regard to the false Messiah, the Son of Perdition, that the motif of doubt and testing is found. He confounds the righteous 'by means of the illusory and deceptive signs which he will perform'. ${ }^{44}$ These miraculous activities will lead many to follow him, which, in a parody of the activities of Jesus, include cleansing of lepers, healing the blind and the paralysed, and casting out demons. The Son of Perdition will also have substantial powers over the natural world, such that he is able to turn the sun dark, change the moon to blood, but also cause trees and vegetation to grow and springs of water to dry up. It is stated of such miracles that 'By means of these illusory signs he will deceive the saints themselves'. ${ }^{4}$ Based on Mark 13:22 and Matthew 24:24, Pseudo-Methodius describes how it is possible for this satanic figure to deceive the elect. His influence will be so great that he is able to 'enter Jerusalem and take his seat in God's Temple, acting as if he were God' ${ }^{46}$ This apocalypse highlights that the theme of doubt and testing is not restricted to Jewish apocalyptic interpretations, and the performance of miraculous signs as a means of establishing authority to rule is part of a wider discourse across Jewish and Christian traditions.

This is further supported by the Christian Syriac Apocalypse of Daniel, which also elaborates on similar motifs. The text has been brought to prominence by the important work of Matthias Henze, who published an edition, introduction and commentary to the text in 2001. With appropriate caution, Henze has dated this apocalyptic work to the first half of the seventh century, as the text must predate Pseudo-Methodius of which it does not seem to be aware despite the enormous popularity of this text from the later seventh century onwards. ${ }^{47}$ In particular, there is no mention of the 'Last Emperor' or the 'sons of Ishmael', the latter of which terms also features in Pirqe de-Rabbi Eliezer 30 and 32 and Nistarot Rabbi Shimon 
ben Yohai as well as Pseudo-Methodius. The text presents a systematic eschatological scheme from the downfall of the fourth kingdom to the final banquet in the heavenly Jerusalem. The text has a historical section, closely following the biblical episodes of the Book of Daniel with elaboration upon the material of the canonical book, followed by an eschatological section, including description of the messianic woes, the Antichrist, the revelation of God and return of Jesus followed by the heavenly Jerusalem, resurrection and final banquet. ${ }^{48}$

Apocalypse of Daniel 22 outlines the appearance of the Antichrist who claims to be Jesus returned. He is the product of an unnatural birth and has a ferocious appearance with horns and red hair. Apocalypse of Daniel 23-24 describe in detail the signs that he will perform, which include the ability to control the sun and the moon and other natural elements such as clouds, wind, rain and rivers. His great stature allows him to traverse oceans and move from one end of the earth to the other three times in a single day. The ability of the Antichrist to perform miracles results in apostasy from Christian communities as 'many will go astray after him, for many signs and wonders he will perform'. ${ }^{49}$ However, the apocalyptic author carefully notes that this satanic individual is unable to perform the resurrection of the dead. ${ }^{50}$ Just as noted of Otot ha-Mashiah and Pseudo-Methodius, here is a Christian apocalyptic tradition that asserts how the activities of the Antichrist persuade many to join him, but emphasises the importance of miraculous tests as a necessary part of the acknowledgment, acceptance, and in this case ultimate downfall, of this satanic figure. ${ }^{51}$

In Christian sources, the role of a deceiver, who gains sway through miraculous signs is based on exegesis of New Testament passages. For example, Revelation 13:13-14 describes the beast that comes out of the earth and: '[...] performed great signs, even causing fire to come down from heaven to the earth in full view of the people. Because of the signs it was given power to perform on behalf of the first beast, it deceived the inhabitants of the earth'. Similarly Mark 13:22, paralleled in Matthew 24:24, in outlining the signs of the end times states that 'false messiahs and false prophets will appear and perform signs and omens to deceive, if possible, even the elect'. This highlights how eschatological motifs are frequently developed through exegesis of biblical texts to support the conclusions made about the apocalyptic end times.

However, with regard to a possible relationship between Jewish and Christian apocalyptic traditions, the miraculous activity of the Son of Perdition in Pseudo-Methodius and the Antichrist in the Syriac Apocalypse of Daniel can be compared to the actions of Armilos, as described in Otot ha-Mashiah. In all these apocalyptic sources, it is worthy of note that it is a satanic figure that uses the performance of miracles and the required signs as a sign of credibility in order to deceive the people. However, there are important differences between the traditions. In Otot ha-Mashiah, it is knowledge of Torah that allows the wise to identify a false eschatological leader, who is ultimately defeated by God; an emphasis that is underscored by the allusion to and critique of Christian 'frivolity' in the text. In contrast, in Pseudo-Methodius the Son of Perdition is only defeated and consigned to hell when Jesus returns from heaven at the apocalyptic end time. ${ }^{52}$ Thus, descriptions of the response to the satanic claimant and his ultimate fate highlight the divergent theological emphases of the texts.

In addition to the motif of a satanic deceiver, other shared themes are found. Otot haMashiah refers to doubts by the Jewish people after the death of Nehemiah and specifically refers to this as a period of testing for the Jewish people themselves, and a means of identifying those who are truly faithful. Such concepts are closely paralleled in PseudoMethodius and the notion of the end times as a period of chastisement for the Christian community. Furthermore, alongside the need for apocalyptic figures to prove their identity is the ability to resurrect as a key indication of authority. Of particular interest is the report of 
the Antichrist in the Syriac Apocalypse of Daniel that 'Many will go astray after him, for many signs and wonders he will perform. However, he is unable to raise the dead'. ${ }^{53}$ It is clear in this Christian apocalypse that the Antichrist can be discovered specifically due to his inability to perform the resurrection of the dead. ${ }^{54}$ In contrast, Sefer Zerubbabel and Pirqe Mashiah place a particular emphasis not only on questioning the identity of the Messiah but also on the ability to conduct resurrection as the primary miracle that will provide confidence in the claimant. It seems that there is not only a shared exegetical context of the need for proof of identity, but also the performance of resurrection as a primary test of authority in these Jewish and Christian apocalyptic traditions.

\section{Jewish and Christian Apocalypticism: A Discourse of Doubt?}

This article has taken steps to explore a prevalent 'discourse of doubt' in apocalyptic literature that cuts across religious boundaries and reflects heightened awareness of religious claims and competition in the seventh-eighth centuries. Across Jewish and Christian apocalyptic writings, the requirement of tests of identity for eschatological figures with claims to religious authority is prevalent. Such tests are generally accompanied by expressions of doubt by the relevant religious community, or sections within it, that lead to a need for signs of authority. This discourse of doubt and associated testing is manifested in different ways in Jewish and Christian apocalyptic traditions, but provides important evidence of shared approaches to understanding the end times, albeit with very different ideas on who will receive the final reward and punishment in the next age. Examination of potential contacts and conflict as evidenced in Jewish and Christian apocalyptic writings of the seventh-eighth centuries can reveal much about the state of Jewish-Christian relations at a formative period for the Abrahamic religions. ${ }^{55}$

In Sefer Zerubbabel and Pirqe Mashiah, the importance of miraculous activity as a validation of authority to lead is clearly seen with regard to the Messiah ben David. In Sefer Zerubbabel, it is a process of transformation of the Messiah, Elijah as his companion and his resurrection of Nehemiah, the Messiah ben Joseph, that affirms the validity of his claims. A very similar pattern is found in Pirqe Mashiah, although with more detailed elaboration of the theme. In this compilation, the Messiah ben David, again accompanied by Elijah, performs seven miracles, including but not only resurrection, but is only finally accepted by the people once he is glorified by God (based on Isaiah 59:17 as in Sefer Zerubbabel) and conducts the general resurrection of the dead. This proof of authority by means of miraculous activity is accompanied by scriptural evidence to show that the expected Messiah ben David is about to arrive and that his actions are the fulfilment of biblical prophecy. The questioning that the Messiah undergoes from different sections of Jewish society, from the people as a whole to specific Patriarchs, highlights the importance of ascertaining his identity as the Messiah. This discourse of doubt in no sense represents a questioning of the possibility of the future arrival of a Messiah ben David, but rather emphasises the importance of being wary of false claims and the need for assurances of religious authority.

In Otot ha-Mashiah, Pseudo-Methodius and the Syriac Apocalypse of Daniel, it is primarily a satanic figure who asserts his identity as redeemer by means of the miraculous. Thus, even within the broadly shared discourse of doubt there are more specific points of commonality. However, in Otot ha-Mashiah, Armilos is recognised by the 'nations' as their saviours, but Nehemiah and his group are unconvinced because of their knowledge of Torah, thus emphasising the importance of Torah even in the eschatological age. In contrast, in Pseudo-Methodius, the Son of Perdition is only defeated by Jesus returned, which highlights how similar traditions can conclude with very different theological positions in support of a 
religious tradition. In the Syriac Apocalypse of Daniel, it is the Antichrist who performs miraculous signs as a means of claiming authority, but interestingly he is unable to perform resurrection, which conversely is seen as a key test of authority for the Messiah ben David in Sefer Zerubbabel and Pirqe Mashiah.

In Otot ha-Mashiah, the Messiah is not tested in the same way - the focus is on Armilos - but, following the death of Nehemiah, sections of the Jewish people are presented as having doubts about redemption that leads to apostasy. This is emphasised by the description of the end as a period of testing of the faithful, which recalls the concept of chastisement of the Christian community in Pseudo-Methodius. This further highlights the theme of competing religious claims as a key motivator for the presentation of doubt and its consequences in the texts. Interestingly, in Sefer Zerubbabel, it is specifically the sages who express doubt, which highlights the extent of concerns over how to identify the 'correct' eschatological figure - and thus the 'correct' religious position - when presented with rival options. This is also emphasised in Pirqe Mashiah by the repeated questioning of the Messiah by different sections of Jewish society, including the Patriarchs. Finally, Pseudo-Methodius and the Apocalypse of Daniel, based on New Testament exegesis, also highlight fears that the elect can be deceived and not identify eschatological figures correctly.

The traditions analysed show that there was a shared approach across Jewish and Christian apocalyptic writings to outline the demand for key apocalyptic figures to demonstrate the validity of their claims. In particular, it is performance of the miracle of resurrection that is a sign of one who holds legitimate authority. This indicates the need to endorse the claims of a given group, which in turn reflects the wider political turmoil of the seventh century and a search for identity and clarification of status in uncertain times. It represents the concerns of both Jews and Christians in the face of repeated conquests and also points to an ongoing debate amongst Jews and Christians about who has the genuine right to religious authority as manifested in theological claims. This conclusion is highlighted especially by the opponents who challenge the status of the Jewish people in Pirqe Mashiah, the critique of 'frivolous revelation' in Otot ha-Mashiah, and the use of biblical proof texts to support the respective claims. Thus, we have a complex situation where the apocalyptic traditions discussed provide evidence of a shared use of motifs and methods of argumentation, whilst the theological emphases of the respective communities with regard to claims of authority, status and vindication diverge. This speaks to a shared approach in Jewish and Christian traditions of a 'discourse of doubt' accompanied by an assertion of religious claims in their responses to the political upheavals of the seventh century.

\section{Notes on contributor}

Helen Spurling is Karten Associate Professor in History at the Parkes Institute for the Study of Jewish/non-Jewish Relations at the University of Southampton. She works on midrashic literature of Late Antiquity, and has published extensively on Jewish-Christian relations in this period, particularly examining the reception of the Book of Genesis, and on the subject of apocalyptic literature.

\section{Notes}

${ }^{1}$ For select analysis of these works, see Martha Himmelfarb, "The mother of the Messiah in the Talmud Yerushalmi and Sefer Zerubbabel," in The Talmud Yerushalmi and Graeco-Roman Culture, vol.3, ed. Peter Schäfer (Tübingen: Mohr Siebeck, 2002), 369-389, Martha Himmelfarb, "Sefer Eliyyahu: Jewish Eschatology and Christian Jerusalem," in Shaping the Middle East; Jews, Christians, and Muslims in an Age of Transition, 400-800 C.E., ed. Kenneth G. Holum and Hayim Lapin (Bethesda, MD: University Press of Maryland, 2011), 223-238, and her various studies on the 
subject, David Biale, "Counter-History and Jewish Polemics Against Christianity: The Sefer Toldot Yeshu and the Sefer Zerubavel," Jewish Social Studies n.s. 6 (1999): 130-45, Wout van Bekkum, "Jewish Messianic Expectations in the Age of Heraclius," in The Reign of Heraclius (610-641): Crisis and Confrontation, ed. Gerrit J. Reinink and Bernard H. Stolte (Leuven: Peeters, 2002), 95-112, Alexei M. Sivertsev, Judaism and Imperial Ideology in Late Antiquity (Cambridge: Cambridge University Press, 2011), Günter Stemberger, "Jerusalem in the Early Seventh Century: Hopes and Aspirations of Christians and Jews," in Jerusalem: Its Sanctity and Centrality to Judaism, Christianity and Islam, ed. Lee .I. Levine (New York: Continuum, 1999), 260-272, Gerrit Reinink, "PseudoMethodius: A Concept of History in Response to the Rise of Islam," in The Byzantine and Early Islamic Near East I: Problems in the Literary Sources, Studies in Late Antiquity and Early Islam 1, ed. Averil Cameron and Lawrence I. Conrad (Princeton: Darwin Press, 1992), 149-187, Robert Hoyland, Seeing Islam As Others Saw It: A Survey and Evaluation of Christian, Jewish and Zoroastrian Writings on Early Islam (Princeton, NJ: Darwin Press, 1997).

${ }^{2}$ A large array of apocalyptic midrashim have been preserved by Adolph Jellinek in his Bet haMidrasch (Jerusalem: Bamberger \& Wahrmann, 1938²), including Sefer Zerubbabel (BHM 2:54-57), Otot ha-Mashiah (BHM 2:58-63) and Pirqe Mashiah (BHM 3:68-78) amongst others. A selection of these apocalypses has recently been translated by John C. Reeves, Trajectories in Near Eastern Apocalyptic: a postrabbinic Jewish apocalypse reader (Leiden; Boston: Brill, 2006). References to Jewish apocalypses in this article are taken from Jellinek's Bet ha-Midrasch unless otherwise stated.

${ }^{3}$ Martha Himmelfarb, "Sefer Zerubbabel," in Rabbinic Fantasies: Imaginative Narratives from Classical Hebrew Literature, ed. David Stern and Mark Mirsky (Philadelphia: Jewish Publication Society, 1990), 67-90, Martha Himmelfarb, "Sefer Zerubbabel and popular religion," in A Teacher for All Generations; Essays in Honor of James C. VanderKam, vol.1-2, ed. Eric F. Mason, et al. (Leiden: Brill, 2012), 621-634, Martha Himmelfarb, "Revelation and rabbinization in Sefer Zerubbabel and Sefer Eliyyahu," in Revelation, Literature, and Community in Late Antiquity, ed. Philippa Townsend and Moulie Vidas (Tübingen: Mohr Siebeck, 2011), 217-236, Lutz Greisiger, "Die Geburt des Armilos und die Geburt des Sohnes des Verderbens: Zeugnisse jüdisch-christlicher Auseinandersetzung um die Identifikation des Antichristen im 7. Jahrhundert," in Antichrist; Konstruktionen von Feindbildern Herausgegeben von Wolfram Brandes und Felicitas Schmieder (Berlin: Akademie, 2010), 15-37, Joseph Dan, "Armilus: the Jewish Antichrist and the origins and dating of the Sefer Zerubbavel," in Toward the Millennium; Messianic Expectations from the Bible to Waco, ed. Peter Schäfer and Mark Cohen (Leiden: Brill, 1998), 73-104, Brannon M. Wheeler, "Imagining the Sasanian capture of Jerusalem: the Prophecy and Dream of Zerubbabel and Antiochus Strategos' Capture of Jerusalem," Orientalia Christiana Periodica 57.1 (1991): 69-85, Abraham Berger, "Captive at the gate of Rome: the story of a messianic motif," Proceedings - American Academy for Jewish Research 44 (1977): 1-17.

${ }^{4}$ See, for example, Haggai 1:1.

5 Averil Cameron, "Blaming the Jews: The Seventh Century Invasions of Palestine in Context," Travaux et Memoires 24 (2002): 57-78, Clive Foss, "The Persians in the Roman Near East (602630)," Journal of the Royal Asiatic Society, series 3, 13.2 (2003): 149-170, John F. Haldon, Byzantium in the Seventh Century (Cambridge: CUP, 1990), James D. Howard-Johnston, East Rome, Sasanian Persia and the end of antiquity: historiographical and historical studies (Aldershot; Burlington, Vt.: Ashgate, 2006), Peter Sarris, "Heraclius, Persia and Holy War," in Empires of Faith: The Fall of Rome to the Rise of Islam, 500-700 (Oxford: Oxford University Press, 2011), 226-272, Hagit Sivan, "From Byzantine to Persian Jerusalem: Jewish Perspectives and Jewish-Christian Polemics," Greek, Roman and Byzantine Studies 41 (2000): 277-306, Robert L. Wilken, "The Jerusalem Above Wept over the Jerusalem Below," in The Land Called Holy: Palestine in Christian History and Thought (New Haven; London: Yale University Press, 1992), 216-232. 
${ }^{6}$ For example, the Messiah ben Joseph is described at length in Sefer Zerubbabel, which builds on traditions such as found in Genesis Rabbah 75.5, 99.2, BT Sukkah 52a, Tg Song of Songs 4:5, 7:4 and Song of Songs Rabbah 4.5.

${ }^{7}$ See notes 1 and 3 .

${ }^{8}$ This image of the Messiah ben David is modelled on Isaiah 52; cf. BT Sanhedrin 98a and Berger, "Captive at the gate of Rome," 1-17. See note 30 for discussion of concepts of suffering messianism in the rabbinic period.

${ }^{9}$ נח is the root for the messianic name Menahem (the comforter) sometimes given to the Messiah ben David; see A. Goldberg, "Die Namen des Messias in der rabbinischen Traditionsliteratur. Ein Beitrag zur Messiaslehre des rabbinischen Judentums," Frankfurter Judaistische Beiträge 7 (1979): 1-93 (3236).

${ }^{10}$ For comparison of this motif with the Christian legend of the 'Last Emperor', see Sivertsev, Judaism and Imperial Ideology, 146-148.

${ }^{11}$ The gloss referring to 'ben Shealtiel' is most likely a confusion with the protoganist Zerubbabel in Jellinek's edition. The Messiah ben Joseph is otherwise named 'Nehemiah ben Hushiel' in textual traditions of Sefer Zerubbabel; see, for example, Jellinek, BHM 2:56.

${ }^{12}$ For messianism in rabbinic traditions more broadly, see, for example, Philip Alexander, "The Rabbis and Messianism," in Redemption and Resistance, ed. Markus Bockmuehl and James CarletonPaget (London: T\&T Clark, 2007), 227-44, Philip Alexander, "The King Messiah in Rabbinic Judaism," in King and Messiah in Israel and the Ancient Near East, ed. John Day (Sheffield: Sheffield University Press, 1998), 456-473, Nicholas de Lange, "Jewish and Christian Messianic Hopes in pre-Islamic Byzantium," in Bockmuehl and Carleton-Paget, Redemption and Resistance, 274-284, Peter Schäfer, "Die messianischen Hoffnungen des rabbinischen Judentums," in Studien zur Geschichte und Theologie des rabbinischen Judentums, ed. Peter Schäfer (Leiden: Brill, 1978), 214243, Joseph Klausner, The Messianic Idea in Israel (London, 1956), Gershom Scholem, The Messianic Idea in Judaism (London, 1971), Chaim Milikowsky, "Trajectories of return, restoration and redemption in rabbinic Judaism," in Restoration; Old Testament, Jewish, and Christian Perspectives, ed. James M. Scott (Leiden: Brill, 2001), 265-280, and especially in the seventh century see Wout J. van Bekkum, "Jewish Messianic Expectations," 95-112.

${ }^{13}$ Cf. Sivertsev, Judaism and Imperial Ideology, 147 who argues that 'the redeemer's burning wrath is the essential part of his revelation'. Isaiah 59:17 describes God rather than the Messiah defeating his enemies; cf. Tg. Isaiah 59:17, Pesiqta de-Rav Kahana 22.5 and S6.5, Pesiqta Rabbati 37.2 and Song of Songs Rabbah 1.9.4.

${ }^{14}$ Elijah is sometimes the forerunner of the Messiah, and at other times he will himself partly realise the promised scheme of salvation; cf. Eccl. 48:1-16, Midrash on Proverbs 19, Pesiqta Rabbati 35.4, Otot ha-Mashiah (BHM 2:62) and Tefillat R. Simeon (BHM 4:125), Aggadat Bereshit (BHM 4:76) and Sefer Eliyahu (BHM 3:65-68) for a detailed description of the activity of Elijah at the end of time. For discussion on the eschatological role of Elijah in haggadic literature, see Karin Hedner-Zetterholm, "Elijah's different roles: a reflection of the rabbinic struggle for authority," Jewish Studies Quarterly 16.2 (2009): 163-182, Karin Hedner-Zetterholm, "Elijah and the Messiah as spokesmen of rabbinic ideology," in The Messiah in Early Judaism and Christianity, ed. Magnus Zetterholm (Minneapolis: Fortress Press, 2007), 57-78, Milikowsky, "Trajectories of return," 265-280, A. Wiener, The Prophet Elijah (London, 1978).

${ }^{15}$ Such religious claims are embodied in Christian writings of the seventh and subsequently Islamic writings of the seventh and eighth centuries. This is exemplified by the writings of Sebeos, a seventh 
century Armenian Christian chronographer whose history covers the period up to the early Arab conquests. He famously describes the relations between Jews, Muslims and Christians at this time and sees the events of the seventh century as a time of fulfilment of Danielic prophecy as a means of highlighting Christian religious claims; see Robert W. Thomson, The Armenian History Attributed to Sebeos: Translated with notes by R.W. Thomson, Historical Commentary by James Howard-Johnston, Assistance from Time Greenwood (Liverpool: Liverpool University Press, 1999), Tim Greenwood, "Sasanian Echoes and Apocalyptic Expectations: A Re-evaluation of the Armenian History Attributed to Sebeos," Le Muséon 115 (2002): 323-97, Robert Hoyland, "Sebeos, the Jews and the Rise of Islam," in Medieval and Modern Perspectives on Muslim-Jewish Relations, ed. R. L. Nettler (Luxembourg: Harwood Academic Publishers, 1995), 89-102, James Howard-Johnston, Witnesses to a World Crisis: Historians and Histories of the Middle East in the Seventh Century (Oxford: Oxford University Press, 2010); cf. also discussion of Pseudo-Methodius and the Syriac Apocalypse of Daniel in this article; for an overview of competing religious claims in this period, see Guy Stroumsa, "False Prophet, False Messiah and the Religious Scene in Seventh Century Jerusalem," in Bockmuehl and Carleton-Paget, Redemption and Resistance, 285-296.

${ }^{16}$ For an overview of questions of dating, see Sivertsev, Judaism and Imperial Ideology, 50-52; cf. Ra'anan S. Boustan, "The Spoils of the Jerusalem Temple at Rome and Constantinople: Jewish Counter-Geography in a Christianizing Empire," in Antiquity in Antiquity: Jewish and Christian Pasts in the Greco-Roman World, ed. Gregg Gardner and Kevin L. Osterloh (Tübingen: Mohr Siebeck, 2008), 327-72 (364).

${ }^{17}$ The origins and development of this infamous figure have been well discussed so will not be rehearsed here; cf. David Biale, "Counter-History," 130-145, Bernard McGinn, Antichrist: Two Thousand Years of the Human Fascination with Evil (San Francisco, 1994; reprinted, New York: Columbia University Press, 2000), David Berger, "Three Typological Themes in Early Jewish Messianism: Messiah Son of Joseph, Rabbinic Calculations, and the Figure of Armilus," Association for Jewish Studies Review 10 (1985): 141-65, Joseph Dan, “Armilus," 73-104, Sivertsev, Judaism and Imperial Ideology, 154-158.

${ }^{18}$ See Gerson Cohen, "Esau as Symbol in Early Medieval Thought," in Jewish Medieval and Renaissance Studies, ed. Alexander Altmann (Cambridge, Mass: Harvard University Press, 1967), 19-48, Helen Spurling, "The Biblical Symbol of Edom in Jewish Eschatological and Apocalyptic Imagery," in Sacred Text: Explorations in Lexicography, ed. Juan-Pedro Monferrer-Sala and Angel Urban (Frankfurt: Peter Lang, 2009), 271-299.

${ }^{19}$ The understanding of Armilos as representing Christianity in Otot ha-Mashiah is also supported by Sivertsev, who argues that Armilos resembles Christian Roman emperors such that 'The figure of Armilos personifies more than just Rome. It personifies the Christian revival of the Roman Empire, serving almost as a caricature of Eusebius' Constantine and subsequent emperors who modelled themselves on Constantine', Sivertsev, Judaism and Imperial Ideology, 155.

${ }^{20}$ See Marc Hirshman, "Torah in Rabbinic Thought: The Theology of Learning," in The Cambridge History of Judaism. Vol. 4, The Late Roman-Rabbinic Period, ed. Steven Katz (Cambridge: Cambridge University Press, 2006), 899-924.

${ }^{21}$ See note 15 .

${ }^{22}$ Zechariah 13:9 refers to an eschatological future where the sheep (i.e. Israel) will be tested, but with only a third surviving to undergo this test, cf. Song of Songs Rabbah 1.22; Ezekiel 20:38 warns Israel (originally those in exile) that those who rebel against God from among them will be judged, cf. TanB Beha'alotekha 13 and Numbers Rabbah 15.12; Daniel 12:10 is part of an apocalyptic vision of the fate of the righteous and the wicked - the wise will understand and purify themselves whereas the wicked will be in ignorance and continue to behave wickedly. 


\begin{abstract}
${ }^{23}$ See note 15 .
${ }^{24}$ For more detail on Pirqe Mashiah, see Helen Spurling, "A Revival in Jewish Apocalyptic? Change and continuity in the seventh-eighth centuries with special reference to Pirqe Mashiah," in Visions of the End: Apocalypticism and Eschatology in the Abrahamic Religions (6th-8th cent. C.E.), ed. Hagit Sivan, Guy Stroumsa and Emmanouela Grypeou, Peeters, forthcoming 2015, Helen Spurling, "The Image of God in Late Antique Apocalyptic Literature: The Holy One as Teacher in Pirqe Mashiah," in Hannah Ewence and Helen Spurling, Visualizing Jews through the Ages (New York: Routledge, 2015), 32-47, Helen Spurling, "Pirqe Mashiah: A Translation, Commentary and Introduction" (PhD Diss., University of Cambridge, 2004), John Reeves, Trajectories, 149-169.
\end{abstract}

${ }^{25}$ For more discussion of such historical allusions, see Spurling, "A Revival in Jewish Apocalyptic?" forthcoming 2015.

${ }^{26}$ Jellinek, BHM 3:72.

${ }^{27}$ Ibid.

${ }^{28}$ On this approach of mirroring the redemption at the Exodus with the redemption at the end of time, see Pesiqta de-Rav Kahana 5.7-9, Ruth Rabbah 2.14 and 5.6 and Pesiqta Rabbati 15.10.

${ }^{29}$ For more detail on the different signs, see Spurling, "A Revival in Jewish Apocalyptic?" forthcoming 2015.

${ }^{30}$ However, the tradition of the Messiah ben David as Ephraim is found in Pesiqta Rabbati 34.2, 36.1,2, 37.1,2, based on Jeremiah 31:9 and 31:20. The broader themes of Pesiqta Rabbati 34, 36-37 are also found in Pirqe Mashiah, as the Messiah of Pesiqta Rabbati speaks with the Patriarchs, is clothed in splendour and kills all the enemies of Israel with the 'breath of his lips', and in addition both include occasions when God will put on clothes of vengeance and refer to the battle between the Kings of Persia and Arabia. The connection between these sections of Pesikta Rabbati and Christian traditions has been thoroughly discussed; see A. Goldberg, Erlösung durch Leiden: Drei rabbinische Homilien über die Trauernden Zions und den leidenden Messias Efraim (PesR 34. 36. 37.) (Frankfurt am Main, 1978), 36, Rivka Ulmer, "Psalm 22 in Pesiqta Rabbati: the suffering of the Jewish Messiah and Jesus," in The Jewish Jesus; Revelation, Reflection, Reclamation, ed. Zev Garber (West Lafayette, IN: Purdue University Press, 2011), 106-128, Michael Fishbane, "Midrash and Messianism: Some Theologies of Suffering and Salvation," in Schäfer and Cohen, Toward the Millennium, 57-71, Peter Schäfer, The Jewish Jesus: How Judaism and Christianity Shaped Each Other (Princeton, NJ: Princeton University Press, 2012), 236-272, Philip Alexander, "The Mourners of Zion and the Suffering Messiah: Pesikta rabati 34---Structure, Theology, and Content," in Midrash Unbound: Transformations and Innovations, ed. Michael Fishbane and Joanna Weinberg (Oxford: Littman, 2013), 137-157.

${ }^{31}$ Cf. Ben Sira 48:10, Tg.P-J. Exodus 40:9-10, Tg.O, Tg.N. and Tg.P-J Numbers 24:7, Tg.P-J Deuteronomy 30:4, and Tg. Jeremiah 33:13. See Chaim Milikowsky, "Notions of exile, subjugation and return in rabbinic literature," in Exile; Old Testament, Jewish, and Christian Conceptions, ed. James M. Scott (Leiden: Brill, 1997) 265-296.

${ }^{32}$ Machpelah is the cave purchased by Abraham for a tomb in Genesis 23:4-20, and Genesis 49:29-32 records that the Patriarchs (i.e. the sleepers of Machpelah) were buried there, namely, Abraham, Isaac and Jacob with their wives Sarah, Rebekah and Leah. Rabbinic traditions also teach that Adam and Eve were buried in the cave of Machpelah, although Adam appears to be resurrected separately in Pirqe Mashiah; cf. Genesis Rabbah 58.4, 58.9, BT Erubin 53a, BT Sotah 13a, BT Baba Batra 58a, Pirqe de-Rabbi Eliezer 36. 
${ }^{33}$ On diverse concepts of resurrection in rabbinic traditions, see Harry Sysling, Tehiyyat ha-metim: the resurrection of the dead in the Palestinian Targums of the Pentateuch and parallel traditions in classical rabbinic literature (Tübingen: Mohr Siebeck, 1996), Alan Avery-Peck, "Resurrection of the body in early rabbinic Judaism," Deuterocanonical and Cognate Literature Yearbook (2009): 243266, Alan Avery-Peck, "Death and afterlife in the early rabbinic sources," in Judaism in Late Antiquity. Pt. IV, ed. Alan Avery-Peck and Jacob Neusner (Leiden: Brill, 2000), 243-266, Reuven R. Kimelman, "The rabbinic theology of the physical," in Katz, Cambridge History of Judaism, 946-976, David Flusser, "Resurrection and angels in rabbinic Judaism, early Christianity, and Qumran," in The Dead Sea Scrolls Fifty Years after Their Discovery; Proceedings of the Jerusalem Congress, July 1997, ed. Lawrence H. Schiffman, Emanuel Tov, and James C. VanderKam (Jerusalem: Israel Exploration Society; Israel Museum, 2000), 568-572, Jacob Neusner, "Death and afterlife in the later rabbinic sources," in Avery-Peck and Neusner, Judaism in Late Antiquity, 267-291, Günter Stemberger, "Zur Auferstehungslehre in der rabbinischen Literatur," Kairos 15 (1973): 238-266.

${ }^{34}$ The concept of death as sleep is bound up with ideas of resurrection; if death is only sleep then you can return and resurrection is merely a reawakening of the dead, cf. Isaiah 26:19, Daniel 12:2, PT Ta'an. 1:1, BT Hagigah 12b and Midrash on Psalms 25.1. This tradition is paralleled in Pesiqta Rabbati 37.1, which records that the Patriarchs will arise and speak to the Messiah named Ephraim, and Lamentations Rabbah proem 1, where Jeremiah goes to the cave of Machpelah and tells the Patriarchs of the world to arise.

${ }^{35}$ The idea of resurrection as an uncovering of dust is developed from Daniel 12:1-4, which refers to 'multitudes that sleep in the dust of the earth' (ורבים מישני אדמת עפר) and also Isaiah 26:19, which refers to the 'inhabitants of the dust' (שכני עפר); cf. PT Ta'an. 1:1, BT Sanhedrin 90b-91a and 92a.

${ }^{36}$ For a general or universal resurrection of the dead, see Daniel 12:1-4, 2 Baruch 49-51:4, 4 Ezra 7:32-37, M Abot 4.29, BT Sanhedrin 92b and Pirqe de-Rabbi Eliezer 34. For resurrection only for Israel, see 2 Maccabees 7:9-36, Sifre Deuteronomy 306, and Genesis Rabbah 13.6. For resurrection of the deserving from either Israel or the nations, see Test. Simeon 6, Test. Levi 18, Test. Judah 25, Test. Zebulun 10 and BT Ta'anit 7a.

${ }^{37}$ The proof text is Isaiah 52:7, which speaks of the one who brings good tidings on the mountains, and in Pirqe Mashiah is understood to refer to the Messiah announcing salvation on the mountains. A number of traditions relate this verse to messianic deliverance at the end of time, e.g. Leviticus Rabbah 9.9, Pesiqta de-Rav Kahana 5.9, Pesiqta Rabbati 15.14/15, Tan Toledot 14, TanB Toledot 20 and Midrash on Psalms 29.2; cf. Tg. Isaiah 53:7, which gives a more detailed description of the announcement of salvation, which is explicitly addressed to the congregation of Zion. Isaiah 52:7 proclaims a message of peace and salvation, and so the use of this verse in Pirqe Mashiah also alludes to the peace that will be found at the end of time, and, in particular, brought about at the time of messianic deliverance through the resurrection; cf. 1 Enoch 10:16-22, 2 Baruch 73:1-4, Leviticus Rabbah 9.9, Pesiqta de-Rav Kahana S5.1-4, Pesiqta Rabbati 35.4 and Deuteronomy Rabbah 5.15.

${ }^{38}$ For reference to gentiles and heretics in Pirqe Mashiah, see Jellinek BHM 3: 69 and 3:77. It is unclear which specific groups are in view, and the references to gentiles and heretics may simply be a rhetorical device designed to highlight the doubts of rival claimants who would question the superior status of the Jews in light of historical reality.

${ }^{39}$ The identity of the minim has been well discussed, see William Horbury, "The Benediction of the Minim and Early Jewish-Christian Controversy," Journal of Theological Studies 33 (1982): 19-61, Philip Alexander, "The Parting of the Ways from the Perspective of Rabbinic Judaism," in Jews and Christians: the parting of the ways, A.D. 70 to 135, ed. James D.G. Dunn (Tübingen: J.C.B. Mohr, Paul Siebeck, 1992), 1-26, Yaakov Teppler, Birkat ha Minim. Jews and Christians in Conflict in the Ancient World (Tübingen: Mohr Siebeck, 2007), Günter Stemberger, "Birkat ha-minim and the 
separation of Christians and Jews," in Judaea-Palaestina, Babylon and Rome; Jews in Antiquity, ed. Benjamin Isaac and Yuval Shahar (Tübingen: Mohr Siebeck, 2012), 75-88.

${ }^{40}$ On dating, see P. J. Alexander, The Byzantine Apocalyptic Tradition (Berkeley, 1985), 13-51 (2425), Andrew Palmer, The seventh century in the West-Syrian chronicles / introduced, translated and annotated by Andrew Palmer; including two seventh-century Syriac apocalyptic texts introduced, translated and annotated by Sebastian Brock; with added annotation and an historical introduction by Robert Hoyland (Liverpool: Liverpool University Press, 1993), 222-242 (225-226); cf. Reinink, "Pseudo-Methodius,"149-187.

${ }^{41}$ Pseudo-Methodius XIII.1, Palmer, The seventh century, 236.

${ }^{42}$ Pseudo-Methodius XII.3, Palmer, The seventh century, 235.

${ }^{43}$ Pseudo-Methodius XIII.11ff, Palmer, The seventh century, 237ff; see Stroumsa, "False Prophet, False Messiah," 285-296, and P.J. Alexander, "The Medieval Legend of the Last Roman Emperor and its Messianic Origin," Journal of the Warburg and Courtauld Institutes 41 (1978): 1-15.

${ }^{44}$ Pseudo-Methodius XIV.8, Palmer, The seventh century, 241.

${ }^{45}$ Pseudo-Methodius XIV.8, Palmer, The seventh century, 241.

${ }^{46}$ Pseudo-Methodius XIV.10, Palmer, The seventh century, 241-242.

${ }^{47}$ Matthias Henze, The Syriac Apocalypse of Daniel (Tübingen: Mohr Siebeck, 2001), 11-22.

48 The significance of this text for understanding the relationship between Jewish and Christian apocalypticism is highlighted by Henze, who notes, 'the Syriac Apocalypse of Daniel is a formidable example of the currency of apocalyptic expectations among Syriac Christians in [the] seventh-century [...] Our text has preserved a plethora of interpretative traditions and apocalyptic elements [... which] are of interest to the historian of biblical interpretation as well as to the student of Jewish and Christian apocalypticism', Henze, Apocalypse, 30-31.

${ }^{49}$ Syriac Apocalypse of Daniel 24, Henze, Apocalypse, 95.

${ }^{50}$ Ibid.

${ }^{51}$ cf. Matthew 11:4, Luke 7:22 and John 7:31, which teach that miracles are proof of Jesus' Messiahship.

${ }^{52}$ In the Syriac Apocalypse of Daniel, it is a powerful angel that captures and destroys the Antichrist.

${ }^{53}$ Syriac Apocalypse of Daniel 24, Henze, Apocalypse, 95; as with Pirqe Mashiah, clearly the Syriac Apocalypse of Daniel has been influenced by the book of Daniel with direct allusion to Daniel 7:25 and 12:7.

${ }^{54}$ Henze also notes a number of parallels in Christian sources to this inability on the part of the Antichrist to conduct the miracle of revivification. He points to the Apocalypse of Elijah 3:12-13 and Pseudo-Ephrem's 'Sermon on the End of the World', 423-424, which explicitly contain this motif, Henze, Apocalypse, 95.

${ }^{55}$ A parallel development can also be seen in early Islamic literature. For example, ibn Ishaq describes how Muhammad was able to miraculously draw water from a rock, A. Guillaume, The Life of Muhammad: a translation of Ishaq's Sirat rasul Allah (Oxford: OUP, 1955); al-Waqidi highlights 
how Muhammad was able to feed large numbers from a single animal, R. Faizer, The Life of Muhammad: Al-Waqidi's Kitab al-Maghazi (Abingdon: Routledge, 2011). Interestingly, both of these examples reflect biblical traditions: Moses producing water from a rock in the wilderness (Exodus 17:1-7) and Jesus feeding the 5000 (Mark 6:31-44, Matthew 14:13-21, Luke 9:10-17 and John 6:5$15)$. 